$$
\text { DOE /PC/89651-- T22 }
$$

\title{
500 MW DEMONSTRATION OF ADVANCED WALL-FIRED COMBUSTION TECHNIQUES FOR THE REDUCTION OF NITROGEN OXIDE EMISSIONS FROM COAL-FIRED BOILERS
}

\author{
John N. Sorge \\ Southern Company Services, Inc. \\ P. O. Box 2625 \\ Birmingham, Alabama 35202 \\ Bill Menzies \\ Radian Corporation \\ P. O. Box 201088 \\ Austin, Texas 78720-1088 \\ We have no objection from a patene \\ stsictpoint to the publication or \\ Scott M. Smouse \\ dsescisnation of this material.

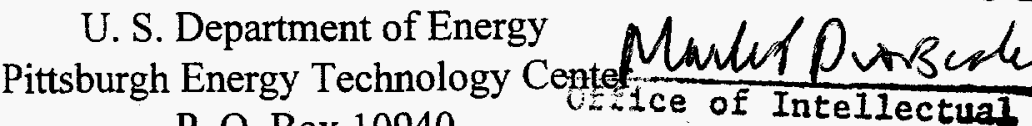 \\ P. O. Box 10940 \\ Pittsburgh, Pennsylvania 15236-0 Property Counsel \\ $8-25-95$ \\ Jeffery W. Stallings \\ Electric Power Research Institute \\ P. O. Box 10412 \\ Palo Alto, California 94303-0813
}

\begin{abstract}
This paper discusses the technical progress of a U. S. Department of Energy Innovative Clean Coal Technology project demonstrating advanced wall-fired combustion techniques for the reduction of nitrogen oxide (NOx) emissions from coal-fired boilers. The primary objective of the demonstration is to determine the long-term NOx reduction performance of advanced overfire air (AOFA), low NOx burners (LNB), and advanced digital control/optimization methodologies applied in a stepwise fashion to a $500 \mathrm{MW}$ boiler. The focus of this paper is to report (1) on the installation of three on-line carbon-in-ash monitors and (2) the design and results to date from the advanced digital control/optimization phase of the project.

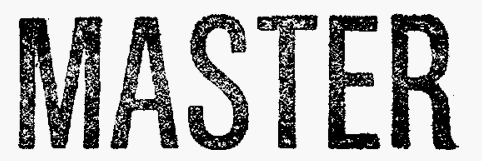




\section{DISCLAIMER}

Portions of this document may be illegible in electronic image products. Images are produced from the best available original document. 


\section{INTRODUCTION}

This paper discusses the technical progress of one of the U.S. Department of Energy's Innovative Clean Coal Technology (ICCT) projects demonstrating advanced combustion techniques for the reduction of nitrogen oxide (NOx) emissions from wall-fired boilers. The demonstration is being conducted on Georgia Power Company's Plant Hammond Unit 4, a 500 MW, pre-NSPS (New Source Performance Standards), wall-fired boiler. Plant Hammond is located near Rome, Georgia, northwest of Atlanta.

The Hammond project is being managed by Southern Company Services, Inc. (SCS) on behalf of the project co-funders: The Southern Company, the U. S. Department of Energy (DOE), and the Electric Power Research Institute (EPRI). In addition to SCS, Southern includes the five electric operating companies: Alabama Power, Georgia Power, Gulf Power, Mississippi Power, and Savannah Electric and Power. SCS provides engineering and research services to the Southern electric system. The ICCT program is a jointly funded effort between DOE and industry to move the most promising advanced coal-based technologies to the commercial marketplace. The goal of ICCT projects is the demonstration of commercially feasible, advanced coal-based technologies that have already reached the "proof-of-concept" stage. The ICCT projects are jointly funded endeavors between the government and the private sector in which the industrial participant contributes at least 50 percent of the total project cost. The DOE is participating through the Office of Clean Coal Technology at the Pittsburgh Energy Technology Center (PETC).

The primary objective of the demonstration is to determine the long-term NOx reduction performance of advanced overfire air (AOFA), low NOx burners (LNB), and advanced digital control/optimization methodologies applied in a stepwise fashion to a $500 \mathrm{MW}$ boiler. Shortterm tests of each technology are also being performed to provide engineering information about emissions and performance trends $[1,2,3,4]$.

Following a brief unit and technology review, this paper focuses on the design and results to date from the advanced digital control/optimization phase of the project.

\section{UNIT AND TECHNOLOGY REVIEW}

Georgia Power Company's Plant Hammond Unit 4 is a Foster Wheeler Energy Corporation (FWEC) opposed wall-fired boiler, rated at $500 \mathrm{MW}$ gross, with design steam conditions of 2500 psig and $1000 / 1000^{\circ} \mathrm{F}$ superheat/reheat temperatures, respectively. The unit was placed into commercial operation on December 14, 1970. Prior to the LNB retrofit in 1991, six FWEC Planetary Roller and Table type mills provided pulverized eastern bituminous coal $(12,900$ Btu/lb, 33\% VM, $53 \% \mathrm{FC}, 72 \% \mathrm{C}, 1.7 \% \mathrm{~S}, 1.4 \% \mathrm{~N}, 10 \%$ ash) to 24 pre-NSPS, Intervane burners. The burners are arranged in a matrix of 12 burners $(4 \mathrm{~W} \times 3 \mathrm{H})$ on opposing walls with each mill supplying coal to four burners per elevation (Figure 1).

During a spring 1991 unit outage, the Intervane burners were replaced with FWEC Controlled Flow/Split Flame (CF/SF) burners. In the CF/SF burner, secondary combustion air is divided between inner and outer flow cylinders. A sliding sleeve damper regulates the total secondary air 


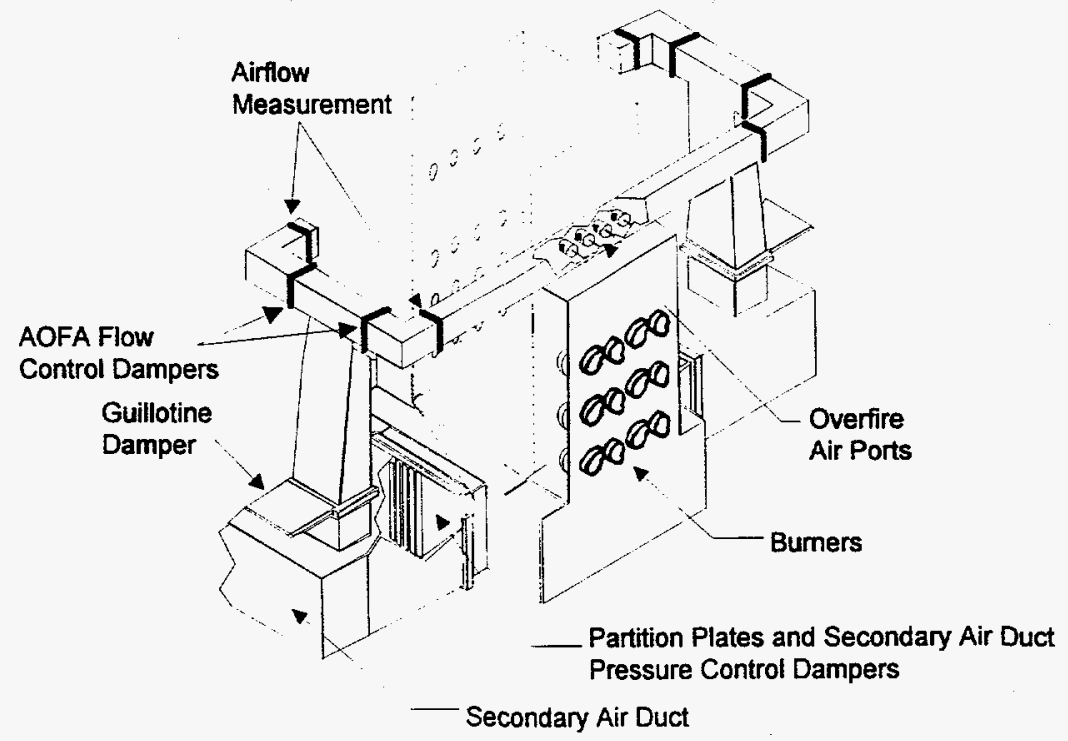

Figure 1. Hammond Unit 4 Furnace Layout

flow entering the burner and is used to balance the burner air flow distribution. An adjustable outer register assembly divides the burner's secondary air into two concentric paths and also imparts some swirl to the air streams. The secondary air that traverses the inner path, flows across an adjustable inner register assembly that, by providing a variable pressure drop, apportions the flow between the inner and outer flow paths. The inner register also controls the degree of additional swirl imparted to the coal/air mixture in the near throat region. The outer air flow enters the furnace axially, providing the remaining air necessary to complete combustion. An axially movable inner sleeve tip provides a means for varying the primary air velocity while maintaining a constant primary flow. The split flame nozzle segregates the coal/air mixture into four concentrated streams, each of which forms an individual flame when entering the furnace. This segregation minimizes mixing between the coal and the primary air, assisting in the staged combustion process.

As part of this demonstration project, the unit was also retrofit with an Advanced Overfire Air (AOFA) system. The FWEC design diverts air from the secondary air ductwork and incorporates four flow control dampers at the corners of the overfire air windbox and four overfire air ports on both the front and rear furnace walls. Due to budgetary and physical constraints, FWEC designed an eight port AOFA system more suitable to the project and unit than the twelve port system originally proposed.

The Unit 4 boiler was designed for pressurized furnace operation but was converted to balanced draft operation in 1977. The unit is equipped with a coldside ESP and utilizes two regenerative secondary air preheaters and two regenerative primary air heaters. During the course of the ICCT demonstration, the unit was retrofitted with six Babcock \& Wilcox MPS 75 mills (two each during the spring 1991, spring 1992, and fall 1993 outages). 


\section{REVIEW OF PRIOR TESTING}

Baseline, AOFA, LNB, and LNB+AOFA test phases have been completed (Table 1). Short-term and long-term baseline testing was conducted in an "as-found" condition from November 1989 through March 1990. Following retrofit of the AOFA system during a four-week outage in spring 1990, the AOFA configuration was tested from August 1990 through March 1991. The FWEC CF/SF low NOx burners were then installed during a seven week outage starting on March 8, 1991 and continuing to May 5, 1991. Following optimization of the LNBs and ancillary combustion equipment by FWEC personnel, LNB testing was commenced during July 1991 and continued until January 1992. Testing in the LNB+AOFA configuration was completed during August 1993. During both the LNB and LNB+AOFA, there were significant increases (when compared to baseline) in precipitator fly ash loading and gas flow rate and also, increases in fly ash LOI which adversely impacted stack particulate emissions and forced the unit to be load limited [5].

\section{Table 1. Project Schedule}

\begin{tabular}{|c|l|c|c|}
\hline Phase & Description & Date & Status \\
\hline 0 & Pre-Award Negotiations & & \\
\hline 1 & Baseline Characterization & $8 / 89-4 / 90$ & Completed \\
\hline 2 & Advanced Overfire Air Retrofit (AOFA) \& Characterization & $4 / 90-3 / 91$ & Completed \\
\hline 3A & Low NOx Burner Retrofit (LNB) \& Characterization & $3 / 91-1 / 92$ & Completed \\
\hline 3B & LNB+AOFA Characterization & $1 / 92-8 / 93$ & Completed \\
\hline 4 & Digital Controls/Optimization Retrofit \& Characterization & $9 / 93-9 / 95$ & In Progress \\
\hline 5 & Final Reporting and Disposition & $9 / 95-12 / 95$ & Later \\
\hline
\end{tabular}

A summary of the baseline, AOFA, LNB, and LNB+AOFA long-term NOx emissions data for Hammond Unit 4 is shown in Figure 2. Baseline testing was performed in an "as-found" condition. For the AOFA, LNB, and LNB+AOFA test phases, following optimization of the unit by FWEC personnel, the unit was operated according to FWEC instructions provided in the design manuals. As shown, the AOFA, LNBs, and LNB+AOFA provide a long-term, full load, NOx reduction of 24,48 , and 68 percent, respectively. The load-weighted average of NOx emissions reductions was 14,48 , and 63 percent, respectively, for AOFA, LNBs, and LNB+AOFA test phases. Although the LNB plus AOFA NOx level represents a 67 percent reduction from baseline levels, a substantial portion of the incremental change in NOx emissions between the LNB and LNB+AOFA configurations is the result of operational changes and is not the result of the AOFA system [6].

The time-weighted average of NOx emissions for the baseline, AOFA, LNB, LNB+AOFA test phases are shown in Table 2. Since NOx emissions are generally dependent on unit load, the NOx values shown in this table are influenced by the load dispatch of the unit during the corresponding test frame. Also shown in this table are the 30 day and annual achievable emission limits as determined during these test periods. The 30-day rolling average achievable emission limit is defined as the value that will be exceeded, on average, no more than one time per ten years. For the annual average, a compliance level of 95 percent was used in the calculation. 


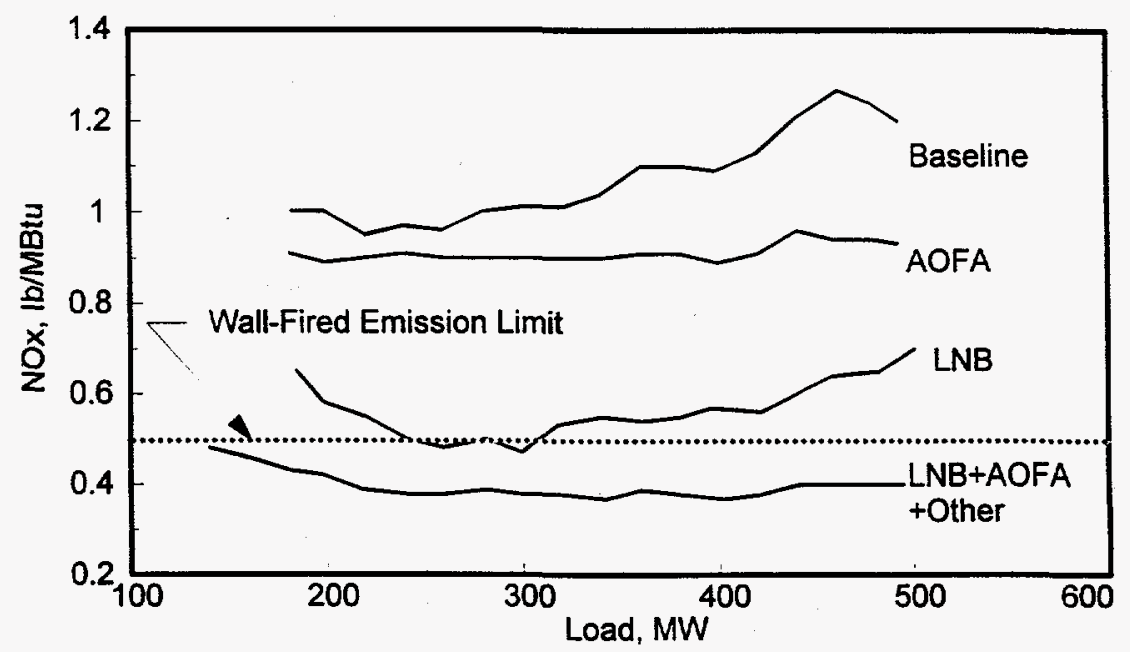

Figure 2. Long-Term NOx Emissions vs. Load Characteristic

Table 2. Long-Term NOx Emissions

\begin{tabular}{|l|c|c|c|c|c|c|c|c|}
\hline Unit Configuration $\rightarrow$ & \multicolumn{2}{|c|}{ Baseline } & \multicolumn{2}{c|}{ AOFA } & \multicolumn{2}{c|}{ LNB } & \multicolumn{2}{c|}{ LNB+AOFA } \\
\hline Parameter $\downarrow$ & Mean & RSD,\% & Mean & RSD,\% & Mean & RSD,\% & Mean & RSD,\% \\
\hline Number of Daily Avg. Values & 52 & - & 86 & - & 94 & - & 63 & - \\
\hline Load (MW) & 407 & 9.4 & 386 & 17.9 & 305 & 17.7 & 293 & 23.9 \\
\hline NOx Emissions (lb/MBtu) & 1.12 & 9.5 & 0.92 & 8.6 & 0.53 & 13.7 & 0.41 & 12.9 \\
\hline O2 Level (percent at stack) & 5.8 & 11.7 & 7.3 & 12.6 & 8.4 & 7.7 & 8.73 & 16.3 \\
\hline NOx 30 Day AEL (lb/MBtu) & 1.24 & - & 1.03 & - & 0.64 & - & 0.51 & - \\
\hline NOx Annual AEL (lb MBtu) & 1.13 & - & 0.93 & - & 0.55 & - & 0.42 & - \\
\hline
\end{tabular}

\section{EVALUATION OF ON-LINE CARBON-IN-ASH ANALYZERS}

A subsidiary goal of the Wall-Fired project is the evaluation of advanced instrumentation as applied to combustion control. Based on this goal, several on-line carbon-in-ash monitors are being evaluated as to their:

- Reliability and maintenance,

- Accuracy and repeatability, and

- Suitability for use in the control strategies being demonstrated at Hammond Unit 4.

Three units are currently installed at this site: (1) Applied Synergistics FOCUS, (2) CAMRAC Corporation CAM, and (3) Clyde-Sturdevant SEKAM. The SEKAM unit samples from two locations at the economizer outlet while the CAM unit samples from a single location at the precipitator inlet (Figure 3). The FOCUS unit is a non-extractive system that utilizes two cameras located above the nose of the furnace. The following paragraphs briefly describe these devices. 


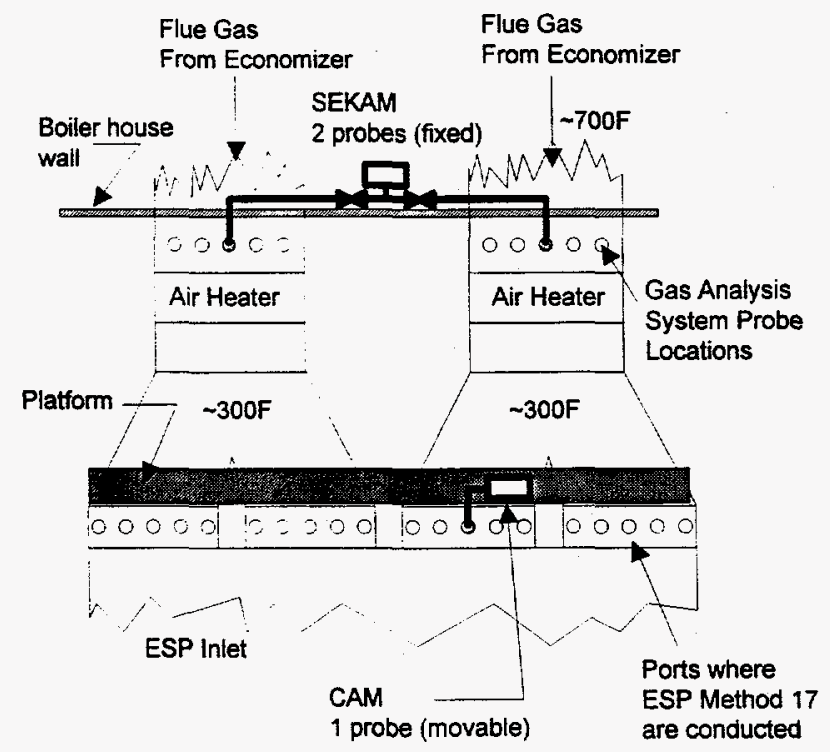

Figure 3. Sample Locations of CAM and SEKAM Carbon-in-Ash Analyzers

\section{Clyde-Sturdevant SEKAM}

The SEKAM ${ }^{\mathrm{TM}}$ unit was developed by the UK Central Electric Generating Board (CEGB). As a result of the dissolution of the CEGB, ownership of the SEKAM technology was eventually transferred to Clyde-Sturdevant Engineering. A sketch of the SEKAM system is shown in Figure 4. The basis of the SEKAM device is the measurement of capacitance of the fly ash sample using a Kajaani cell which was developed by the Finish firm Kajaani Limited. Ash collected from the flue gas stream (or other locations) is deposited in a glass chamber of rectangular cross section measuring $150 \times 70 \times 20 \mathrm{~mm}(5.91 \times 2.76 \times 0.79$ inches) placed between two capacitance sensors. The cell, flyash, and sensors are integrated into a circuit such that the output

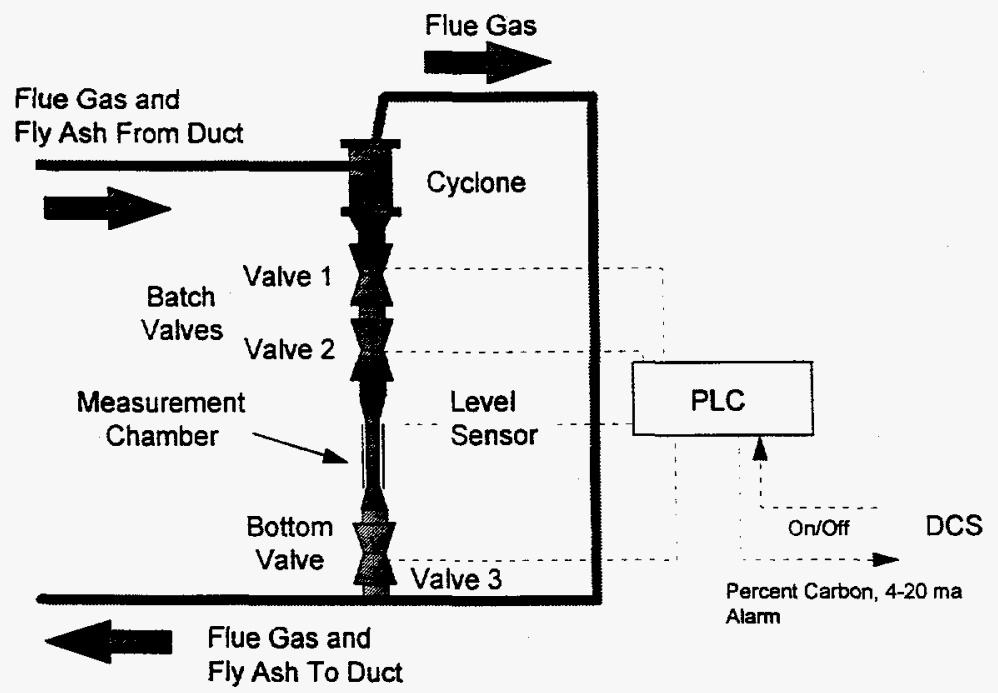

Figure 4. SEKAM General Arrangement 
voltage of the circuit is a function of the measured capacitance. The device presumes a fixed relationship between the measured capacitance and carbon-in-ash. The installation at Hammond Unit 4 can sample from either the "A" or "B" side economizer outlet gas stream or from both probes simultaneously. It is expected that, except for short-term testing, the SEKAM will be configured to extract flue gas from both the " $A$ " and " $\mathrm{B}$ " sides simultaneously thus shortening the sampling cycle time and improving the likelihood of obtaining a representative fly ash sample. Since the SEKAM device requires a relatively large fly ash sample (approximately 150 $\mathrm{cm} 3 \sim 375 \mathrm{~g}$ ), in order to reduce the overall sampling time, the system samples superisokinetically. An exhauster is used to supply the motive force to transport the flue gas and fly ash. Super-isokinetic sampling can have either a positive or negative impact on overall sampling accuracy.

The SEKAM system was installed on Hammond 4 during December 1994. Testing is now being conducted to verify the accuracy of the SEKAM system.

\section{CAMRAC CAM}

CAMRAC Company's CAM (Carbon-Ash-Monitor) unit was developed during the 1980s by GAI Consultants (an affiliate of CAMRAC Company) with financial support from Allegheny Power Services Corporation, Duquesne Light Company, New England Power Services, NYSEG, Southern Company Services, Virginia Power, and EPRI. The CAM system uses the relative microwave absorbence between carbon and carbon-free fly ash to infer the carbon content of the sample. A schematic of a CAM system is shown in Figure 5. The installation at Hammond Unit 4 samples from one of twenty sample ports located at the inlet to the precipitator. The system has been designed such that vertical traverses of the flue gas stream can be conducted.

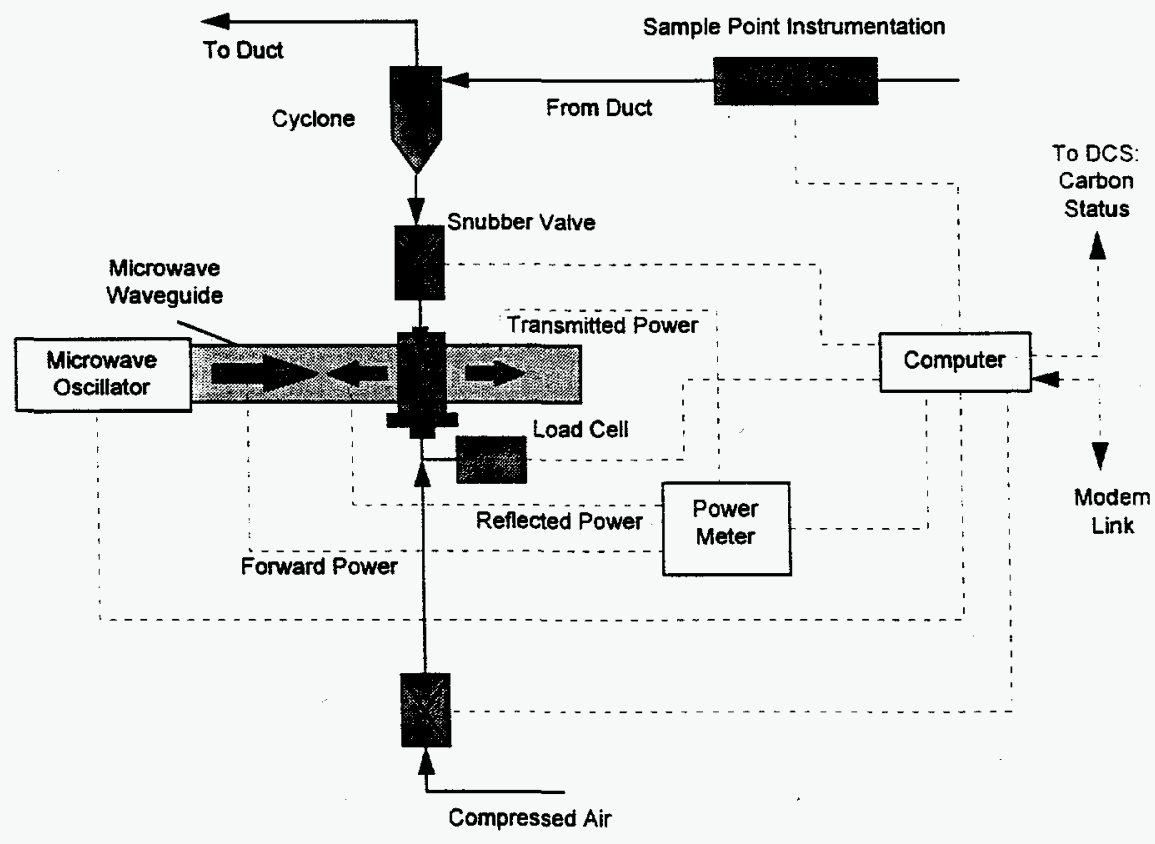

Figure 5. CAMRAC General Arrangement 
During long-term testing, fly ash samples will be drawn from a single location. For short-term testing, several sample ports and depths will be used so that a spatial distribution of the unburned carbon can be obtained.

The CAM system was installed on Hammond 4 during February 1995. Testing is now being conducted to verify the accuracy of the CAM system.

\section{Applied Synergistics FOCUS}

The Applied Synergistic's FOCUS ${ }^{\mathrm{TM}}$ Unburned Carbon Module is a non-intrusive real-time device which provides a timely, continuous on-line indication of unburned carbon in fly ash. The device is based on the premise that unburned carbon particles and carbon laden ash particles exiting the furnace will be hotter than the surrounding background gases, carbon-free ash particles, and support structures, and therefore the carbon-laden particles will be higher emitters of radiant energy, especially in the infrared range. The primary sensing elements are one or more near infrared video cameras installed on the furnace. The hotter particles will be seen as white spots traversing the camera(s) field of view and these images are processed to determine the number of traverses in counts per minute. The assumption is then made that the carbon-in-ash (on a percent basis) is a function of these counts and unit load. Two cameras are utilized at Hammond 4. A sketch of the system is shown in Figure 6.

The FOCUS Unburned Carbon Module was installed during July 1995. Testing of this device for calibration and verification purposes has begun.

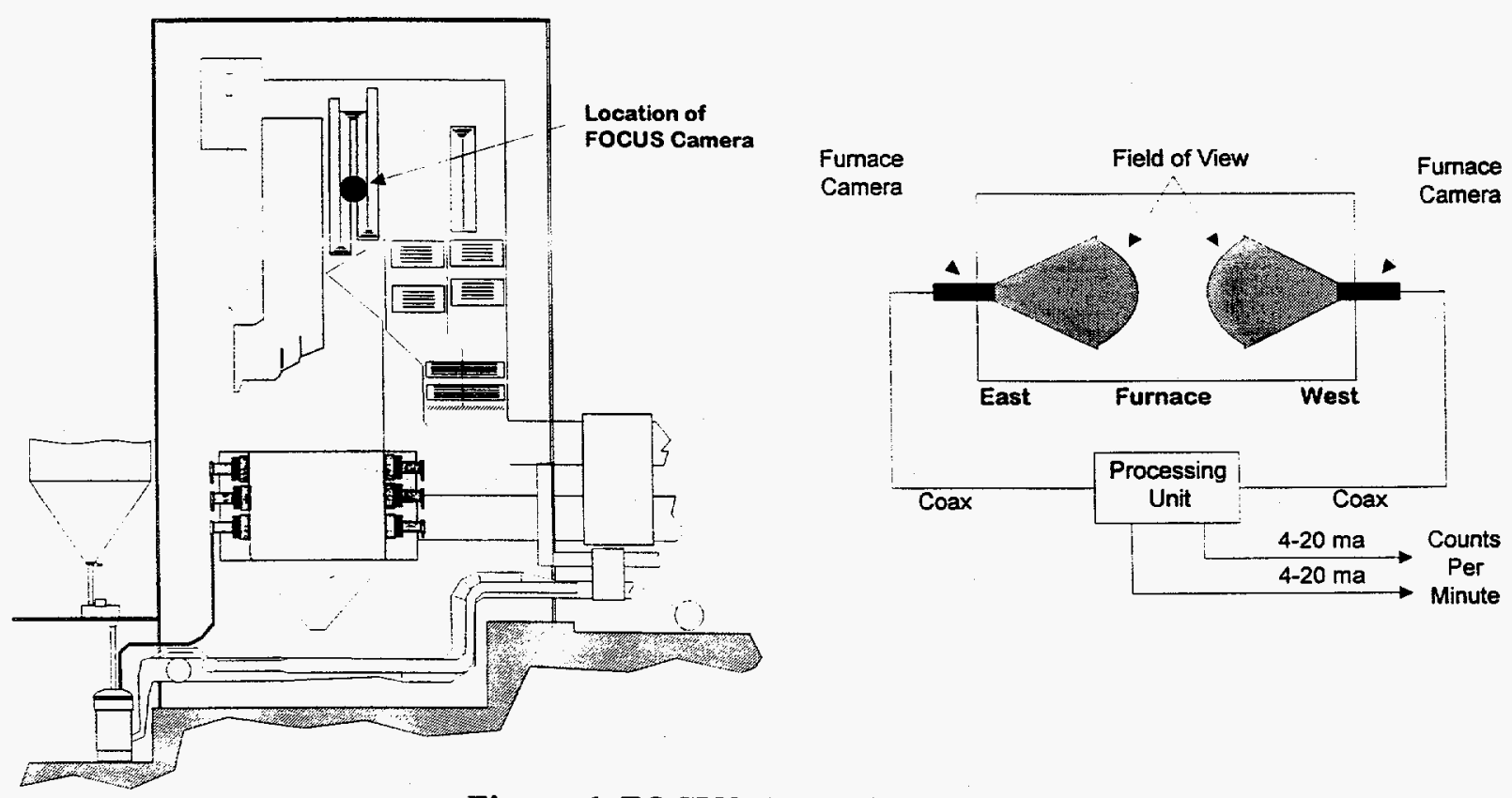

Figure 6. FOCUS General Arrangement 


\section{PHASE 4 - ADVANCED CONTROLS / OPTIMIZATION}

As a result of the installations of the low NOx combustion systems at Hammond 4, combustion optimization has become significantly more difficult than prior to these retrofits. This added difficulty is a result of several factors including:

- Heightened concern and awareness of combustion conditions as a result of the passage of the 1990 Amendments to the Clean Air Act,

- Increased sensitivity of combustion conditions to process adjustments, and

- Additional complexity and more independent tuning adjustments.

The objective of this scope addition to the project at Plant Hammond is to evaluate and demonstrate the effectiveness of advance digital control/optimization methodologies as applied to the NOx abatement technologies installed at this site (LNB and AOFA). The major tasks for this project addition include: (1) design and installation of a distributed digital control system (DCS), (2) instrumentation upgrades, (3) advanced controls/optimization design and implementation, and (4) characterization of the unit both before and after activation of the advanced strategies. Major milestones for this phase of the Wall-Fired Project are shown in Table 3.

Table 3. Advanced Controls / Optimization Major Activities

\begin{tabular}{l|c}
\hline \multicolumn{1}{c|}{ Milestone } & Status \\
\hline Digital control system design, configuration, and installation & Completed \\
Digital control system startup & Completed \\
Instrumentation upgrades & Completed \\
Advanced controls/optimization design & In Progress \\
Characterization of the unit prior to activation of advanced strategies & Scheduled 8/94 - 4/95 \\
Characterization of the unit following activation of advanced strategies & Scheduled Summer 1995 \\
\hline
\end{tabular}

Combustion optimization is the procedure by which NOx reduction, combustion performance, and safety are balanced to achieve or approach a predetermined goal. In most instances, the goals are defined in terms of performance inequality constraints mutually agreed to by the burner vendor and the utility such as:

- NOx - Reduce to below guarantee value and/or compliance limit.

- Fly ash loss-on-ignition (LOI) - Hold below guarantee value and/or state imposed state utilization limit.

- Boiler performance - Maintain above the guarantee value.

These goals may be defined for one or more operating conditions. Only when all constraint goals are clearly met, will further NOx optimization be performed. Due the complexity of the combustion process, optimization is formidable unless the goals are lax. Combustion 
optimization for the low NOx burners with advanced overfire air is considerably more difficult than that required for setup of turbulent burners alone. This added difficulty is a result of the increase in the number of adjustments and sensitivity of these burners to operating conditions (Table 4).

Table 4. Combustion Tuning Control Points at Hammond 4

\begin{tabular}{l|c}
\hline \multicolumn{1}{|c|}{ Pre-LNB+AOFA Retrofit } & Post-LNB+AOFA Retrofit \\
\hline Burners & Burners \\
Sleeve registers (24) & Sleeve registers (24) \\
Secondary air & Tip Positions (24) \\
Windbox balancing dampers & Inner registers (24) \\
Mill Biasing & Outer registers (24) \\
& Advanced overfire air \\
& Can-in-can dampers (8) \\
& Flow control dampers (4) \\
& Secondary air \\
& Windbox balancing dampers \\
& Boundary air \\
\hline
\end{tabular}

Generally, optimization requires that the unit be taken out of economic dispatch and run at fullload for much of the optimization period. After balancing the secondary air flows, the burner optimization process is accomplished by adjusting the inner registers, outer registers, slide nozzles, and sleeve dampers while monitoring $\mathrm{NO}_{\mathrm{x}}, \mathrm{O}_{2}$, and $\mathrm{CO}$ at the economizer outlet. When possible, burner adjustments of the same class (the classes being inner register, outer register, slide nozzle, or sleeve damper) are moved in unison to a nominal, optimized position. Only when flow and/or combustion irregularities dictate, are individual dampers adjusted from this nominal position. The adjustments to the sleeve dampers, inner registers, outer registers, and tip position are made during the burner optimization process and thereafter remain fixed unless changes in plant operation or equipment condition dictate further adjustments. The normal FWEC practice is to supply actuators on the sleeve dampers only. Optimization is performed for full-load operation and performance is checked at lower loads. Because of the constraints of the equipment and optimization methodology, the combustion process can be optimized for one operating condition (load, fuel condition, air distribution, etc.) and therefore is sub-optimal for all others.

Unlike $\mathrm{SO}_{2}$ emissions which are primarily a function of the sulfur content of the fuel, NOx emissions are highly dependent on a number of parameters. Nitrogen oxides (NOx) are formed in combustion processes through the thermal fixation of atmospheric nitrogen in the combustion air producing "thermal NOx" and the conversion of chemically bound nitrogen in the fuel producing "fuel NOx". NOx emissions can theoretically be reduced by lowering: (1) the primary flame zone $\mathrm{O}_{2}$ level, (2) the time of exposure at high temperatures, (3) the combustion intensity, and (4) primary flame zone residence time. NOx emission rates are strongly influenced by the apportionment of the air to the burners and AOFA system. 
An example of the interdependencies and conflicting goals which must be considered can be seen in Figure 7. As shown, as excess air (or equivalently, excess oxygen) decreases, NOx decreases while LOI increases. High LOI values are indicative of poor combustion and therefore poor boiler performance. Also, on units which sell their fly ash (Hammond 4 does not at this time), an increase in fly ash LOI can change the fly ash from a marketable commodity to an undesirable byproduct. A decision must be made as to what is the optimum operating condition based on economic and environmental considerations. Similar compromises must also be made when optimizing boiler efficiency. In this case, the optimum operating condition is clear as long as the performance index is defined as boiler efficiency and other parameters (such as NOx emissions) are not considered. Conflicting objectives such as these have been observed on Hammond Unit 4. As shown in Figure 8, the NOx production rate is an increasing function of the excess oxygen level while fly ash LOI is a decreasing function. This data was collected during the short-term low NOx burner tests.

In addition to variations with excess oxygen levels and load, $\mathrm{NO}_{\mathbf{x}}$ emissions also vary significantly during long-term operation and it is evident that a number of uncontrolled and unidentified variables greatly influence $\mathrm{NO}_{\mathrm{x}}$ production. These influencing variables are believed to be mill operating conditions (primary air temperatures, air/fuel ratios, flows, grind, and moisture), secondary air non-uniformity (air register settings, forced draft fan bias, and windbox pressure differential), coal variability, etc. As shown in Figure 9, NOx long-term variability at Hammond Unit 4 for the LNB plus AOFA test phase was approximately $0.07 \mathrm{lb} / \mathrm{MBtu}$ at full load, increasing to $0.3 \mathrm{lb} / \mathrm{MBtu}$ at minimum load. As can be seen, there are significant differences in the NOx emission characteristics although no changes in burner adjustments or operating procedures were made during this time frame. A potential goal of any on-line optimization program installed at this site would be to drive NOx emissions down to the lower percentile and beyond.
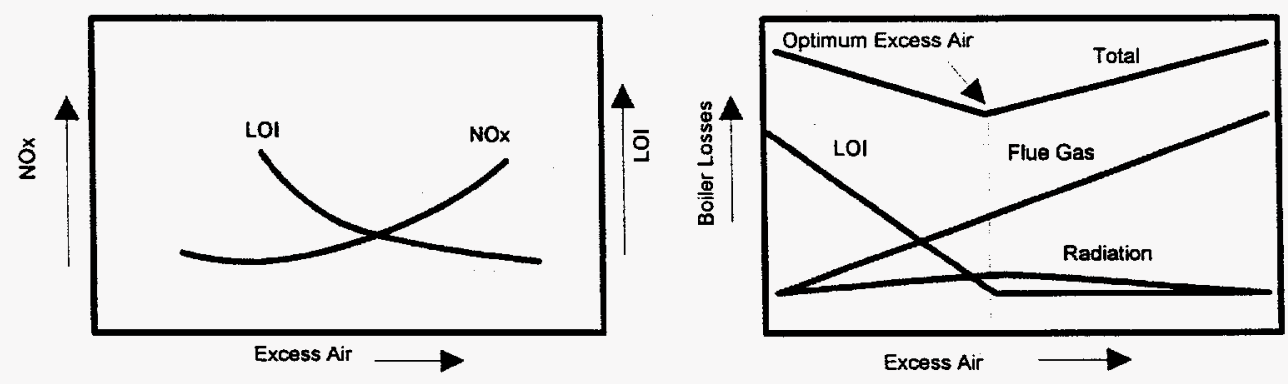

Figure 7. Typical Tradeoffs in Boiler Optimization 


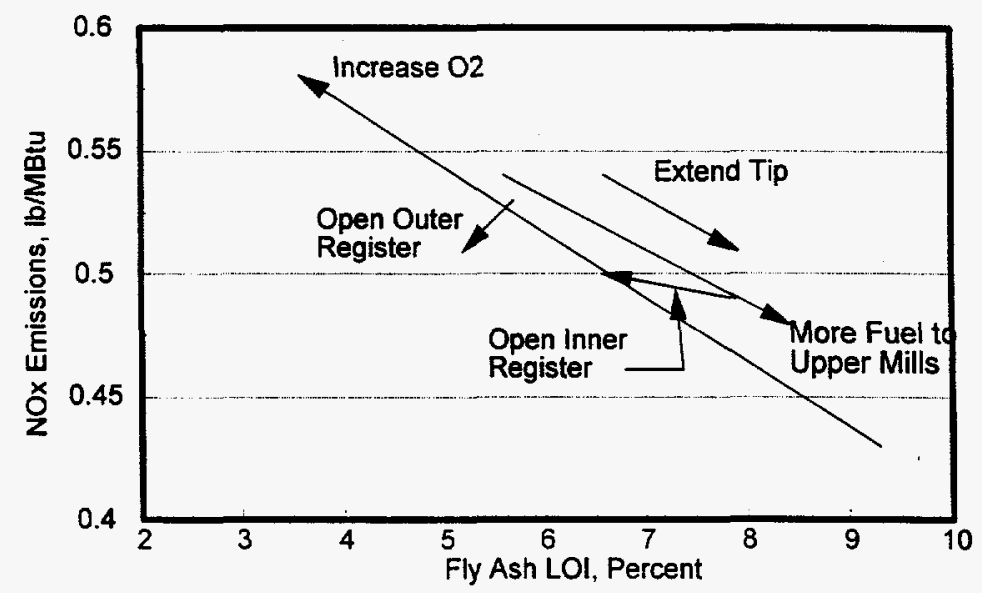

Figure 8. NOx and LOI vs. Excess Oxygen (NOx vs. LOI Tests)

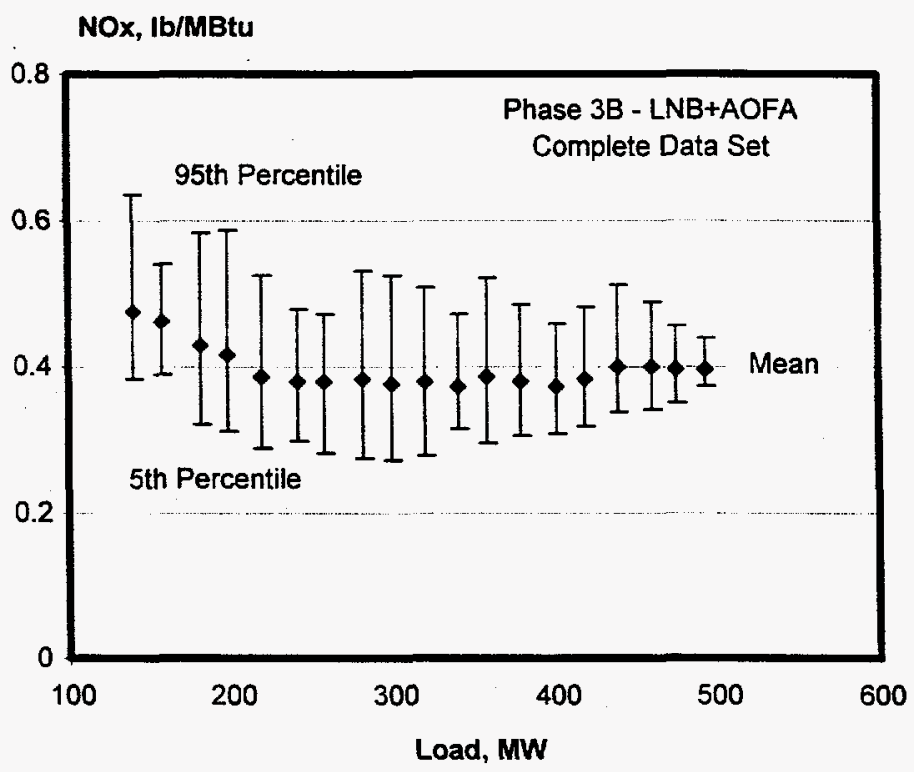

Figure 9. Long-Term NOx Emissions During LNB Plus AOFA Test Phase 


\section{Generic NOx Control Intelligent System}

The optimization methodology to be demonstrated at Hammond is the Generic NOx Control Intelligent System (GNOCIS) whose development is being funded by a consortium consisting of the Electric Power Research Institute, PowerGen, The Southern Company, U.K. Department of Trade and Industry, and U.S. Department of Energy [7]. The objective of the GNOCIS project is to develop an on-line enhancement to existing digital control systems that will result in reduced NOx emissions, while meeting other operational constraints on the unit (principally heat rate and other regulated emissions). The main contractors for the development of GNOCIS are PowerGen and Southern Company Services. Commercializers for North America are SCS and Radian Corporation. In its role as commercializer, Radian is already deeply involved in the demonstrations in the U.S. PowerGen and one other as yet unnamed organization will be the commercializers in Europe.

The core of the system is a neural-network model of the combustion characteristics (such as $\mathrm{NO}_{\mathbf{x}}$ emissions and fuel efficiency) of a boiler, that reflects both short-term and longer-term shifts in boiler emission characteristics. The software applies an optimizing procedure to identify the best set points for the plant. The recommended set points are conveyed to the plant operators via the DCS or, at the plants discretion, the set points can be implemented automatically without operator intervention. The software incorporates sensor validation techniques and is able to operate during plant transients (i.e. load ramping, fuel disturbances, and others). Figure 10 shows the major elements of GNOCIS.

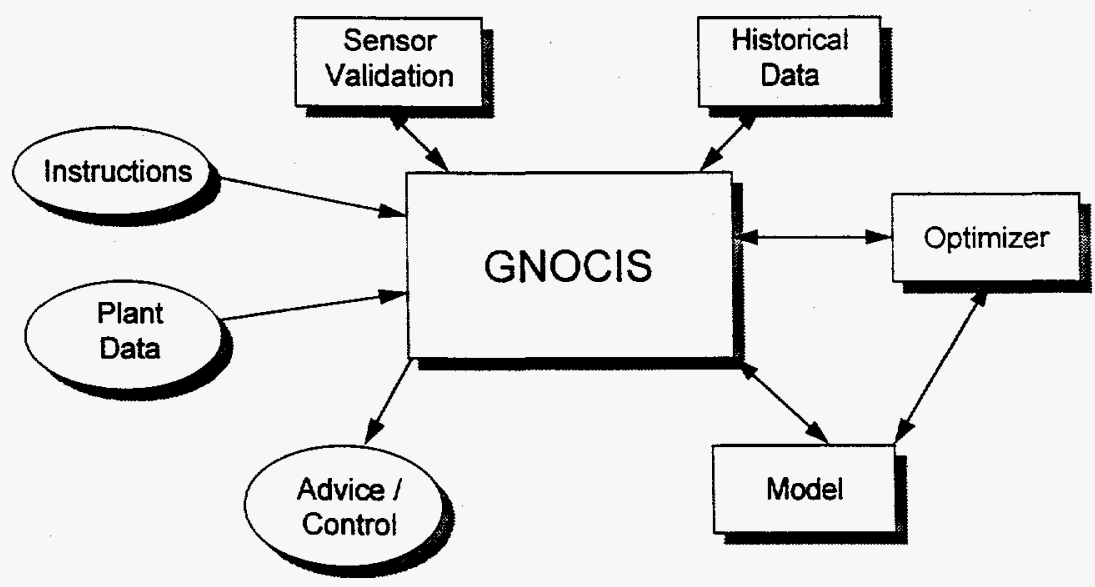

Figure 10. Major Elements of GNOCIS

Following an initial feasibility study in which several promising methodologies were evaluated, a software package from Pavilion Technologies was selected to fulfill the "core" technology role in GNOCIS, i.e. to form the basis of the process and control models necessary to perform on-line optimization. The models are created from data collected from long-term, normal operation, augmented as necessary by short-term testing. 
GNOCIS methodology is now undergoing testing at PowerGen's Kingsnorth Unit 1 (a 500 MW tangentially-fired unit with an ICL Level 3 Low NOx Concentric Firing System) and Alabama Power's Gaston Unit 4 (a 250 MW B\&W unit with B\&W XCL low NOx burners), the results of which have been reported elsewhere [8].

Customization of GNOCIS at Hammond is now underway. The major activities associated with the GNOCIS installation at Hammond 4 are:

- Digital Control System Design, Configuration and Installation

- Instrumentation Upgrades

- Pre-Installation Testing

- Model and Optimization Strategy Development

- Post-Installation Testing

These elements are discussed in the following paragraphs.

Digital Control System Design, Configuration, and Installation

An integral part of Phase 4 of the project was the design and installation of a digital control system (DCS) to be the host of the advanced control/optimization strategies being developed. Prior to the installation of this DCS, Hammond Unit 4 utilized a pneumatic boiler control system which would be unsuitable for a closed-loop implementation of GNOCIS, therefore it was necessary to upgrade this system. SCS Engineering and Georgia Power had overall responsibility for the following major activities associated with this task:

- Preliminary engineering,

- Procurement,

- Detail engineering,

- Digital control system configuration, and

- Installation and checkout.

In total, the digital control system was configured for 2352 input/output points consisting of 572 analog inputs, 116 analog outputs, 1032 digital inputs, and 632 digital outputs with the balance being allocated spares. This system is designed such that the $\mathrm{I} / \mathrm{O}$ is fully distributed and operator interaction with the digital control system is almost exclusively through the operator display -there are no benchboard mounted manual/auto stations or switches.

An overview of the digital control system is shown in Figure 11. Based on a competitive evaluation, a Foxboro I/A system was selected for installation. The milestones in the design, installation, and startup of the Hammond Unit 4 digital control system are shown in Table 5.

As part of this project, the control room was modified to accept the new Unit 4 digital control system. Pre-existing Unit 4 benchboards were removed and replaced with a CRT based control panel. In addition to the upgrades to Unit 4, Georgia Power has upgraded Unit 3 and is also considering upgrading the digital control systems on Units 1 and 2. Digital control system and control room modifications for Units 1,2, and 3 are not a part of the Wall-Fired Project. 
The Unit 4 DCS has been interfaced with the other DCS's at the site. Unit 3, Unit 4, and Electrical DCS systems are connected through a dual-redundant IEEE 802.3 (Ethernet) local area network (LAN). Through this LAN, the three DCSs are able to share process information and graphics. If for some reason either the A or B LAN fails, all DCSs can maintain normal operation. An additional benefit of these LANs are the ability to share costly resources such as engineering consoles, historical drives, etc. In addition to the inter-DCS network, the Unit 4 DCS (and the others also), are connected through a router to the plant's token-ring PC engineering and administrative LAN and the corporate wide area network (WAN) (Figure 12). The latter enables remote access of process data and facilitates software maintenance. A Sun Sparcstation 5, hosting the GNOCIS software, is connected to this network. The router isolates the DCS from the plant LAN and company WAN.

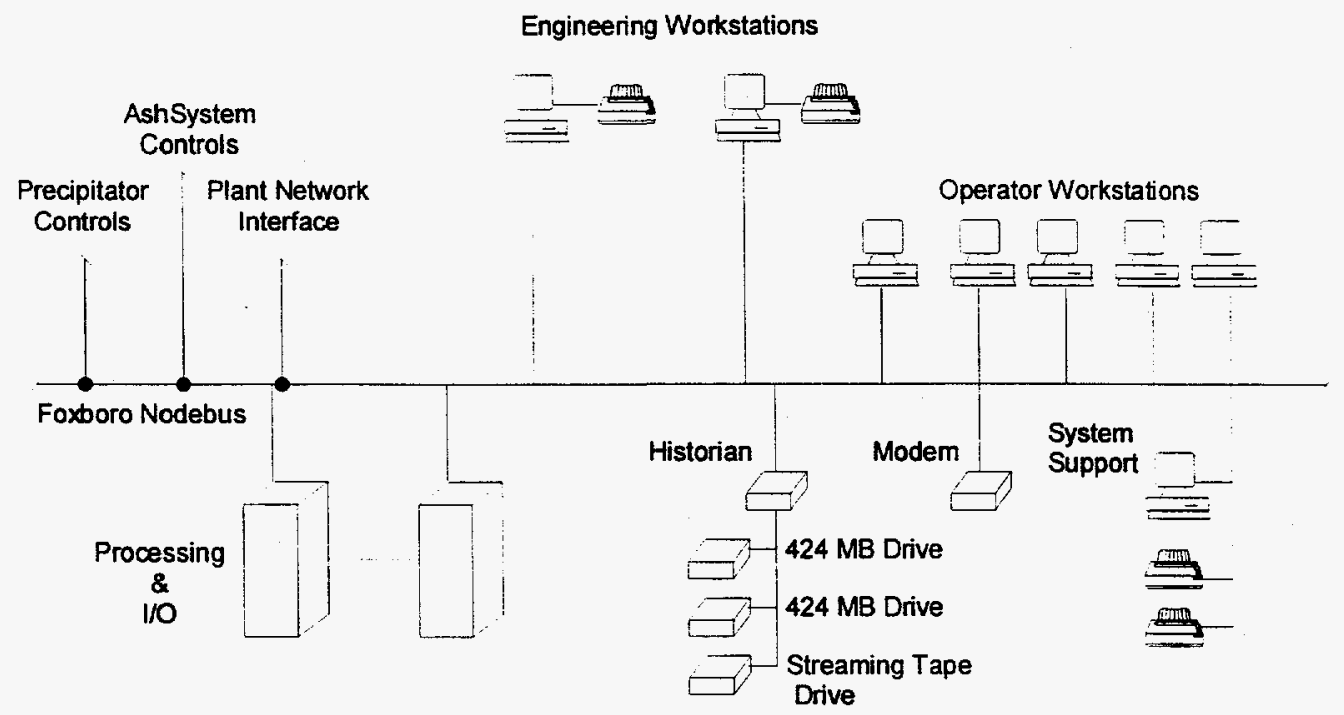

Figure 11. Hammond Unit 4 DCS Overview

Table 5. DCS Installation Milestones

\begin{tabular}{|c|c|}
\hline$\overline{\text { Date }}$ & Milestone \\
\hline June 1992 & - Begin preliminary engineering \\
\hline August 1992 & - Issue request for proposals for digital control system \\
\hline February 1993 & - Foxboro I/A system received at SCS \\
\hline April 1993 & - Issue purchase order to Foxboro \\
\hline June 1993 & - Start detail engineering \\
\hline June 1993 & - Begin configuration \\
\hline January 1994 & - Configuration complete \\
\hline & - Start checkout \\
\hline February 1994 & - Foxboro I/A system shipped to Plant Hammond for installation \\
\hline May 1994 & - Installation complete \\
\hline June 1994 & - Unit Startup \\
\hline
\end{tabular}




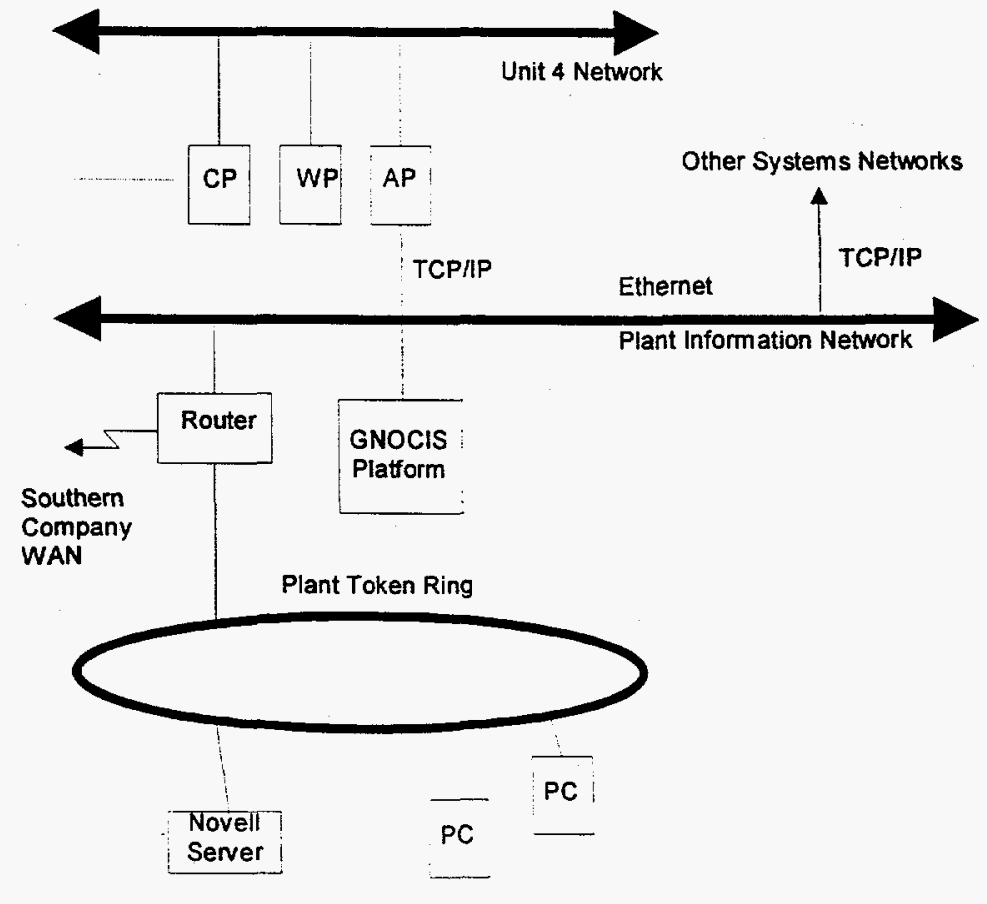

Figure 12. Hammond Plant Network

\section{Pre-Installation Testing}

One prerequisite of a GNOCIS installation is the availability of substantial and high quality process data from the host site. At Hammond, this need was amplified in that a goal of the project is to comprehensively test the performance of GNOCIS. Short-term diagnostic testing was conducted during August 1994 and March 1995, and more comprehensive performance testing was undertaken in November 1994. The primary objectives of these tests were to:

- Re-characterize the unit following a number of combustion modifications during the most recent outage,

- Establish relationships between control variables and measured variables,

- Establish the impact of off-design operational settings, and

- Augment the database used for training of GNOCIS models.

Based on these tests, NOx emissions were found to be approximately $0.43 \mathrm{lb} / \mathrm{MBtu}$-- slightly higher that $0.40 \mathrm{lb} / \mathrm{MBtu}$ observed during Phase 3B testing -- with corresponding fly ash loss-onignition levels near 8 percent. This latter value is similar to what had been observed during Phase $3 \mathrm{~B}$ testing.

Long-term collection of data to be used for training for this phase has been in progress since summer 1994. Although this represents a large volume of information and satisfactory GNOCIS 
models could potentially be developed using a subset (one to two months) of this long-term, normal operating data only, it was felt that by obtaining process information in off-design conditions, the combustion models would be more robust. The need to conduct additional testing depends on the variability of data contained in the training set. Unfortunately, although having many advantages otherwise, digital control systems tend to create highly correlated data in which it is difficult to ascertain emission sensitivities to a number of potential control parameters. One example where this is likely is in mill loadings. Typically, when in service and in automatic, all mills are constrained to equal fuel flows and therefore, unless there is some variability, models can not be created based on process data alone, that can estimate the impact of individual mill flows on important combustion properties such as NOx emissions. The short-term test suite was planned to artificially create the off-design operating conditions that may not be seen during normal unit operation.

\section{Model and Optimization Strategy Development}

Retrieval of process data from the digital control system is now in progress and initial modeling efforts have begun. The first step in the design process is the development of suitable predictive models. An example of the results from a typical non-linear predictive model of NOx and carbon-in-ash are shown in Figures 13 and 14, respectively. In this example, the inputs to the network were coal flows, excess $\mathrm{O}_{2}$, and overfire air flows. The data collected from the DCS and used in training was five minute averages. Steps which could have been taken to improve the prediction capabilities include the addition of more process data and time averaging. Due to the long response time of the on-line carbon-in-ash devices, especially at reduced loads, the modeling of this parameter is generally much more difficult than modeling NOx emissions.

Although predictive models are useful in a number of circumstances, what is required of GNOCIS are control models. Considerations in control model development are sensitivities of model outputs (such as boiler efficiency and $\mathrm{NO}_{\mathrm{x}}$ emissions) to available inputs, and control points readily changeable by the operator or through the DCS.

Design of the control strategy for Hammond 4 is now in progress. As a starting point, it is planned to used the control variables as shown in Table 6. The control variables in the first tier will be implemented initially, and, if successful, additional variables from the subsequent tiers will be considered if their inclusion improves the performance of the system significantly. Software hooks have been designed into the DCS to facilitate the incorporation of these signals into the control logic.

\section{DISCLAIMER}

This report was prepared as an account of work sponsored by an agency of the United States Government. Neither the United States Government nor any agency thereof, nor any of their employees, makes any warranty, express or implied, or assumes any legal liability or responsibility for the accuracy, completeness, or usefulness of any information, apparatus, product, or process disclosed, or represents that its use would not infringe privately owned rights. Reference herein to any specific commercial product, process, or service by trade name, trademark, manufacturer, or otherwise does not necessarily constitute or imply its endorsement, recommendation, or favoring by the United States Government or any agency thereof. The views mendation, or favoring by the Uns of authors expressed herein do not necessarily state or reflect those of the United States Government or any agency thereof. 


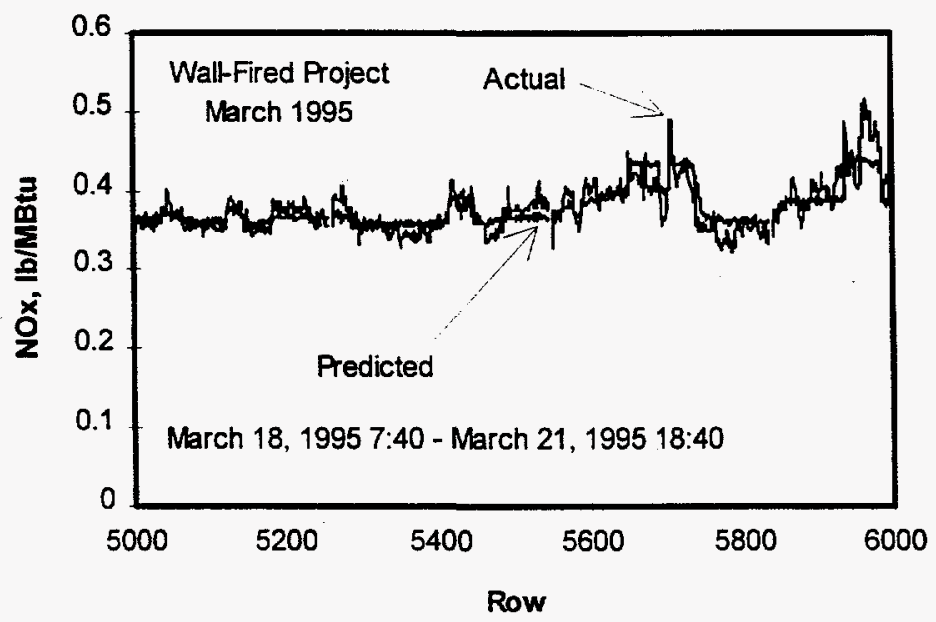

Figure 13. NOx Predictive Model

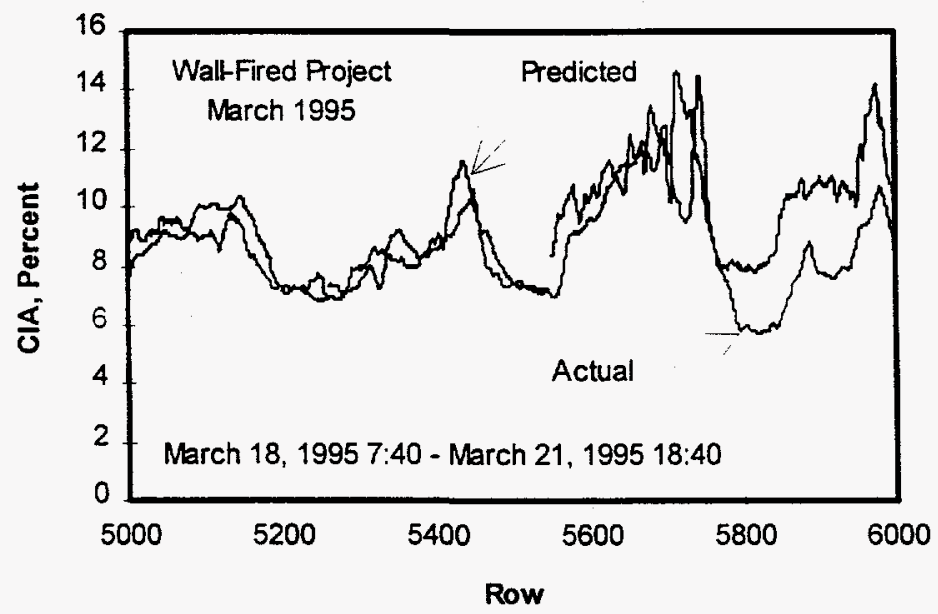

Figure 14. Carbon-in-Ash Predictive Model 
Table 6. Planned Control Variables

\begin{tabular}{l|c|c|c}
\hline \multicolumn{1}{|c|}{ Parameter of Interest } & Controlled Parameter & $\begin{array}{c}\text { Advisory } \\
\text { Mode } \\
\text { Open-Loop }\end{array}$ & $\begin{array}{c}\text { Supervisory } \\
\text { Mode } \\
\text { Close-Loop }\end{array}$ \\
\hline $\begin{array}{l}\text { First Tier } \\
\text { Overall Furnace Air / Fuel Ratio } \\
\text { Overall Furnace Staging }\end{array}$ & Excess O2 Bias & $\mathrm{Y}$ & $\mathrm{Y}$ \\
AOFA Distribution & AOFA Flow (4) & $\mathrm{Y}$ & $\mathrm{Y}$ \\
Mill Biasing & AOFA Flow (4) & $\mathrm{Y}$ & $\mathrm{Y}$ \\
Mills-in-Service & Mill Coal Flow (6) & $\mathrm{Y}$ & Advise \\
Second Tier & Mill Coal Flow (6) & $\mathrm{Y}$ & $\mathrm{Y}$ \\
AOFA Distribution & AOFA Can Dampers (8) & $\mathrm{Y}$ & $\mathrm{Y}$ \\
Furnace Secondary Air Distribution & Bumer Sleeve Damper s by Banks (8) & $\mathrm{Y}$ & $\mathrm{Y}$ \\
Third Tier & Burner Sleeve Damper s (24) & $\mathrm{Y}$ & \\
Furnace Secondary Air Distribution & & & \\
\hline
\end{tabular}

Using the combustion models thus developed, predictions can be made as to the benefits that can be obtained by the application of GNOCIS. For example, as shown in Figure 15, predicted CIA levels near 5 percent were achieved using optimized control setpoints (fuel biasing, excess $\mathrm{O}_{2}$, overfire air flow rates). The corresponding recommended excess $\mathrm{O}_{2}$ levels are shown in Figures 16 and 17. Although the recommended setpoints may not be feasible for actual long-term operation, this scenario does at least lend hope that opportunities may be present for significant CIA reductions. Again, these are predicted results, and although encouraging, they need to be substantiated with thorough plant testing.

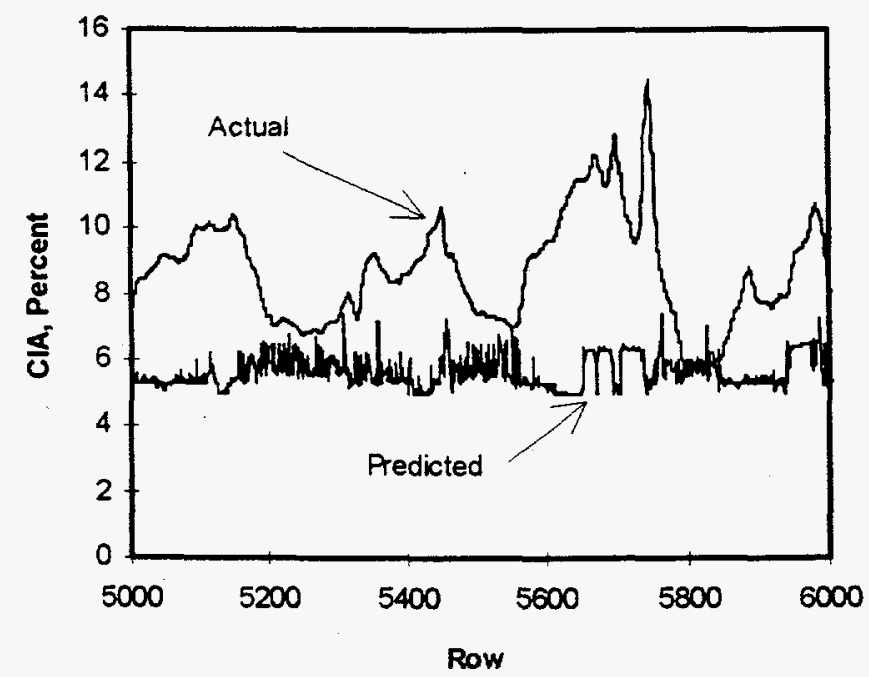

Figure 15. Control Model - Predicted CIA Output (Preliminary) 


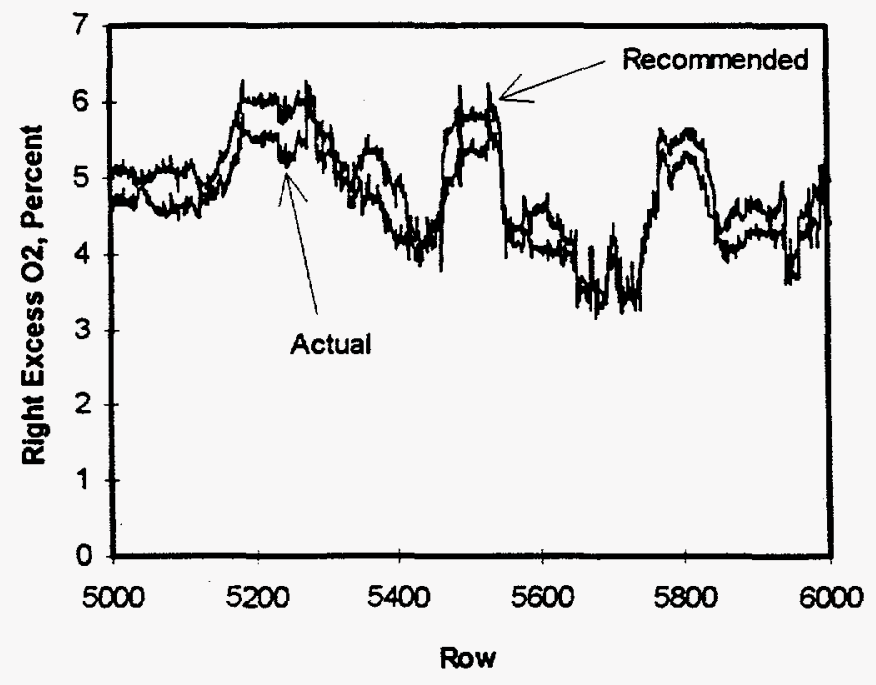

Figure 16. Control Model - Recommended Right Excess $\mathrm{O}_{2}$ (Preliminary)

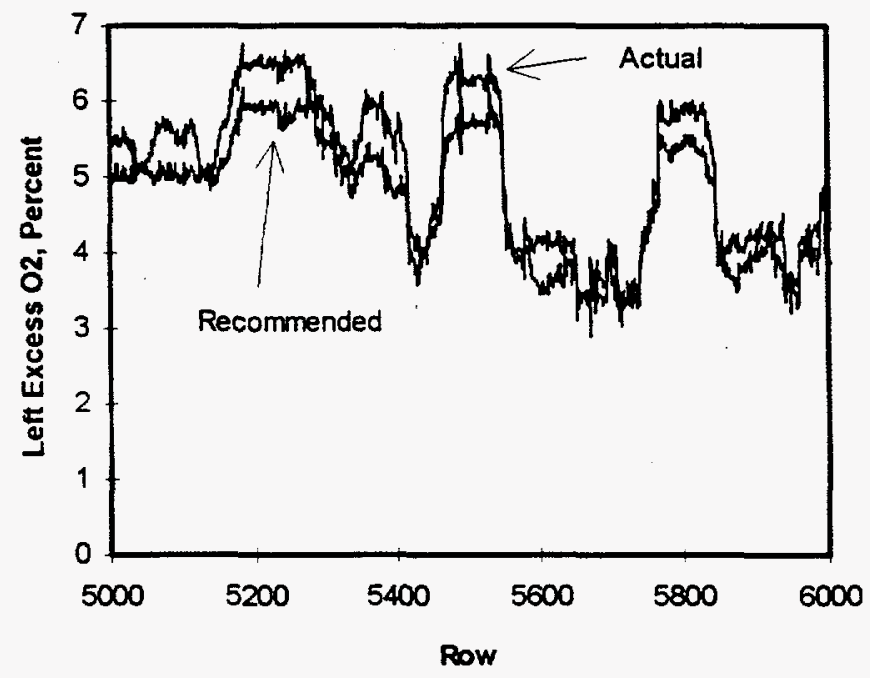

Figure 17. Control Model - Recommended Left Excess $\mathrm{O}_{2}$ (Preliminary)

\section{Post-Installation Testing}

Testing of GNOCIS is scheduled to commence summer 1995 in both open-loop-advisory and close-loop-supervisory modes. The test program is now scheduled for completion during third quarter 1995. 


\section{SUMMARY}

Work is still in progress at Hammond Unit 4. A summary of the current status and plans for this site are as follows:

- Long-term data set collected and it is now being filtered to remove bad and irrelevant data,

- Predictive and control model development is in progress,

- The GNOCIS software is being installed on the Sun Sparcstation 5 and interfaced with the DCS,

- Operator displays are being developed and integrated into the operator consoles, and

- Open- and closed-loop testing of GNOCIS at Hammond 4 is scheduled to commence summer 1995.

\section{ACKNOWLEDGMENTS}

The authors wish to gratefully acknowledge the support and dedication of the following personnel: Mr. Ernie Padgett and Mr. W. C. Dunaway, Georgia Power Company, and Mr. Scott Allison, Mr. Bob Kelly, Mr. Mike Nelson, Southern Company Services, for their coordination of the design and retrofit efforts, and Mr. Jose Perez, Instrumentation Specialist from Spectrum Systems, Inc. We would also like to recognize the following companies for their outstanding testing and data analysis efforts: Energy Technology Consultants, Inc., Flame Refractories, Inc., Innovative Combustion Technologies, Southern Research Institute, and W. S. Pitts Consulting. Finally, the support from Mark Perakis, EPRI Project Manager, is greatly appreciated.

\section{REFERENCES}

1. $500 \mathrm{MW}$ Demonstration of Advanced Wall-Fired Combustion Techniques for the Reduction of Nitrogen Oxide Emissions from Wall-Fired Boilers - Phase 1 Baseline Tests. Southern Company Services, Birmingham, AL: 1991.

2. $500 \mathrm{MW}$ Demonstration of Advanced Wall-Fired Combustion Techniques for the Reduction of Nitrogen Oxide Emissions from Wall-Fired Boilers - Phase 2 Overfire Air Tests. Southern Company Services, Birmingham, AL: 1992.

3. $500 \mathrm{MW}$ Demonstration of Advanced Wall-Fired Combustion Techniques for the Reduction of Nitrogen Oxide Emissions from Wall-Fired Boilers - Phase 3A Low NOx Burner Tests. Southern Company Services, Birmingham, AL: 1994.

$4500 \mathrm{MW}$ Demonstration of Advanced Wall-Fired Combustion Techniques for the Reduction of Nitrogen Oxide Emissions from Wall-Fired Boilers - Phase 3B Low NOx 
Burner plus Advanced Overfire Air Tests. Southern Company Services, Birmingham, AL: 1995.

5. $500 \mathrm{MW}$ Demonstration of Advanced Wall-Fired Combustion Techniques for the Reduction of Nitrogen Oxide (NOx) Emissions from Coal Fired Boilers - Technical Progress Report - Third Quarter 1991. Southern Company Services Inc., Birmingham, AL: 1992.

6. Sorge, J., Wilson, S., " 500 MW Demonstration of Advanced Wall-Fired Combustion Techniques for the Reduction of Nitrogen Oxide (NOx) Emissions from Coal Fired Boilers," Third Annual Clean Coal Technology Conference, September 6-8, 1984, Chicago, Illinois.

7. Holmes, R., Squires, R., Sorge, J., Chakraborty, R., McIlvried, T., "Progress Report on the Development of a Generic NOx Control Intelligent System (GNOCIS)," EPRI 1994 Workshop on NOx Controls for Utility Boilers, May 11-13, 1994, Scottsdale, Arizona.

8 Holmes, R., Mayes, I., Irons, R., Sorge, J. N., Stallings, J. W., "GNOCIS An Update of the Generic NOx Control Intelligent System," EPRI/EPA 1995 Joint Symposium on Stationary NOx Control, May 15-19, 1995, Kansas City, Missiouri. 